\title{
From Old Boys to Men and Women of the Corporation: The Americanization and Commodification of Australian Sport
}

\author{
Jim McKay \\ The University of Queensland
}

\author{
Toby Miller \\ Murdoch University
}

\begin{abstract}
Although there are obvious American influences on Australian popular culture, the term "Americanization" is of limited help in explaining the elaborate form and content of Australian sport. The recent transformation from amateur to corporate sport in Australia has been determined by a complex array of internal and international social forces, including Australia's polyethnic population, its semiperipheral status in the capitalist world system, its federal polity, and its membership in the Commonwealth of Nations. Americanization is only one manifestation of the integration of amateur and professional sport into the media industries, advertising agencies, and multinational corporations of the world market. Investment in sport by American, British, New Zealand, Japanese, and Australian multinational companies is part of their strategy of promoting "good corporate citizenship," which also is evident in art, cinema, dance, music, education, and the recent bicentennial festivities. It is suggested that the political economy of Australian sport can best be analyzed by concepts such as "post-Fordism," the globalization of consumerism, and the cultural logic of late capitalism, all of which transcend the confines of the United States.
\end{abstract}

Australians absorb American culture like blotting paper. (Joan Nelson Algren, creator of Sesame Street) ${ }^{1}$

American showbusiness intruding into the start of the big game is inappropriate for a code so Australian. (History Professor Geoffrey Blainey's comment on the 1990 Australian Rules football grand final)

Despite Australians' ambivalence toward American culture, the United States has had profound economic, political, military, and cultural impacts on Australian history. Both the form and content of Australian popular culture-food, music, clothing, and mass media-are permeated with American motifs, products, and methods. One of the great cultural ironies of 1989 occurred

Jim McKay is with the Department of Anthropology and Sociology, The University of Queensland, St. Lucia, Qld. 4072, Australia. Toby Miller is with the School of Humanities, Murdoch University, Murdoch, WA, 6150, Australia. 
when the Critics' Circle of Australia voted Dead Poets' Society best foreign film of the year. The film was directed by Peter Weir, who is an Australian (for the 6 months of the year that he is not in Hollywood). Such a paradox symbolizes the imbalance in the flow of images between the two countries. That same year, Australia sold 10 of its feature films to the United States and imported 250 in return.

\section{The Rise of Corporate Sport in Australia}

Until fairly recently, Australian sport was less affected by American influences than other spheres of popular culture. Like other "white settler societies" (e.g., Canada, New Zealand, South Africa), English sports and the amateur ethos have been ascendant for much of Australia's history. Before 1980 only a few Australian (male) athletes made a full-time career out of playing sport, and most professional team sports were voluntarily administered by "old boys." In less than a decade the form and content of Australian sport have changed dramatically. ${ }^{2}$ The once hegemonic amateur ideology has become increasingly marginal and residual, as all professional (men's) sports have been reorganized on the basis of management science with executive directors and specialists in advertising, marketing, and public relations. Most amateur and semiprofessional men's and women's sports have also become reliant on corporate support for player development, equipment, facilities, coaching, dissemination of information, publicity, and administrative costs. Australian athletes like Greg Norman, Wayne Gardner, and Pat Cash receive enormous amounts of prize, sponsorship, endorsement, and appearance monies. The 1980s were also characterized by burgeoning legal cases in sport related to restraint of trade, salary caps, sponsorship rights, use of corporate logos, and media control. Another indicator of corporate expansion into sport is the noticeable shift in the media regarding the location of sporting news. Sport continues to have its own section in daily and weekly newspapers and magazines, but items now also routinely appear in marketing, financial, computer, and business columns. Articles on sport and advertisements using sporting themes are increasingly found in leading business magazines.

Three main factors have influenced the professionalization and commodification of Australian sport. The first occurred in 1977 when media baron Kerry Packer usurped control of cricket, one of Australia's most popular spectator sports, from the amateur Australian Cricket Board and the International Cricket Conference (Miller, 1989). Packer signed individual players to lucrative contracts for his World Series Cricket (WSC), which was organized on the basis of 1-day packages as well as the 5-day format of traditional test matches. Packer spectacularized cricket with innovations such as colored uniforms, night games, white balls, limited overs, and extra cameras. WSC quickly became a very popular genre both to attend and to watch on television.

The second incident was Australia's dramatic victory in the 1983 America's Cup. Politicians, business leaders, advertisers, the mass media, and mem-

${ }^{1}$ Cited in Adams (1990).

${ }^{2}$ For detailed analyses of these developments, see Lawrence and Rowe (1986a), McKay (in press), McKay and Rowe (1987), and Rowe and Lawrence (1990). 
bers of sporting organizations hailed the victory as evidence of how a combination of patriotism, corporate management, and high technology could give Australia the winning edge in the tough competitive conditions of the world market (James, 1986; McKay \& Huber, 1988). Following the 1983 success, the 1987 defense in Fremantle became a huge corporate project that involved local, state, and national levels of government and domestic and multinational corporations. National and transnational companies spent over $\$(A) 200$ million on various forms of support for the event. The merchandising manager for General Motors Holden (GMH), the manufacturer of "Australia's own car," explained why his company had paid \$(A)350,000 to the Royal Perth Yacht Club for the right to be an official sponsor:

Our sponsorship is image-inspired rather than sales-inspired . . . It's the corporate image we want to promote, the image of an Australian car, and its perception of GMH as an Australian company.

What is ironic, and of particular interest to this paper, is that GMH is an American-owned subsidiary and the parent company in Detroit was a major sponsor of the yacht, America II, in the 1987 race.

The third major event has been the integration of sport, leisure, and recreation into strategies for managing the fiscal and hegemonic crises of the state. Like the Canadian context (Macintosh \& Whitson, 1990), federal bureaucrats and politicians in Australia have contributed to the commodification of sport by implementing corporate, nationalistic, and scientistic policies (James, 1986; McKay, 1986, 1990; Poynton \& Hartley, 1990).

The commercial successes of WSC and the America's Cup and policies of commodification by the state have motivated advertisers, marketers, the mass media, and entrepreneurs to invest considerable sums of money in sports sponsorship and ownership. Australian companies spent \$(A)70 million on sponsorship of sport in 1988. In 1966 some 250 hours of sport was screened by Australian television networks; by 1986 this figure had jumped to nearly 1,400 hours (admittedly, with an increase in the number of networks from 3 to 5). Televised sport is cheap, popular among young men with a high disposable income, and assists commercial networks in meeting the quota of local content set by the Australian Broadcasting Tribunal.

\section{"Damn Yankees"}

Some aspects of this shift from amateur to corporate sport can be directly and indirectly attributed to American influences. Before discussing these American motifs, it is worth mentioning the sometimes tense relations that have been present in sporting contacts between Australia and the United States, although direct sporting competition between the two nations is fairly limited. At a team level, Davis Cup tennis is the most significant contest; individually, golf and sailing are two of the other direct sites of competition. In some sporting contests Australians have complained that their boxers, race horses, and yachtsmen have been met with arrogance and treachery from those "damn Yankees" in the face of "native" Australian excellence (Mandle, 1978; McKay \& Huber, 1988; Stratton, 1986). As we were completing this paper, the captain of Australia's Davis Cup team was accusing the U.S. Tennis Association of duplicity in hosting the 
1990 contest between the two nations. The Americans were strongly condemned for announcing that they intended to import clay material from Germany which suited the American style of play. Tennis Australia claimed that the use of an imported surface probably contravened International Tennis Federation rules. The Australians also claimed that starting times were deliberately scheduled to disadvantage their team. At the same time, a watchdog committee of citizens, the Friends of the Australian Broadcasting Corporation, was complaining that the publicly owned network should go off the air rather than screen "trivial, Americanised crap" such as Oklahoma, Showboat, and American football hosted by an American-born entertainer who lives in Australia.

These protestations aside, American influences on Australian sport have rapidly become taken for granted during the past decade. The Channel Nine network has a 4-hour program every Saturday afternoon called Wide World of Sports, which usually has a considerable amount of American content. Like its American counterpart, the Australian program resembles the postmodern concept of "info-tainment," a pastiche of regular sporting fare and titillating pseudo-sports such as ostrich racing, professional wrestling, darts, dog trials, and arm-wrestling.

Two of the major professional football codes (Rugby League and Australian Rules), and basketball have recently opted for the showbiz format (e.g., cheerleaders, mascots, live bands, and spectacular displays before, during, and after events). The season finales in Australian Rules football and Rugby League have imitated the style of the Superbowl and both events are publicized as extravaganzas. Two of the most popular television commercials on Australian television for the past few years have featured the American singer, Tina Turner, promoting Rugby League. The premier tennis championship is named the Ford Australian Open. Australian networks televise the World Series, the Superbowl, the Kentucky Derby, and major events in American golf, tennis, automobile, and motorcycle racing. One of the five national networks televises a "game of the week" from the NFL and NBA, and professional wrestling matches from the USA are telecast on a regular basis. American football, which is called gridiron in Australia, has recently established amateur leagues in three states, although most teams are located in the capital cities. In Queensland the state league is sponsored jointly by brewers of the American beer, Budweiser, and Power, a local brewery. There is also a magazine about gridiron, which is distributed nationally. It is a case of when, not if, an entrepreneur brings NFL teams to Australia for an exhibition contest.

The most Americanized game is basketball: in 1990 about one quarter of the players and 6 of the 19 coaches in the National Basketball League (NBL) were Americans; the league's most valuable player award has been won by an American every year but one. Since the league restricts the number of nonAustralians to two per team, it becomes important to recruit American immigrants who have become Australian citizens. Thus the starting five for some clubs, in front of their "home" fans, is often composed of three naturalized Australian-Americans and the quota of two American foreign nationals. This American presence has facilitated the popularity of basketball. Whereas 10 years ago the Brisbane Bullets played before a few hundred people in a suburban tin shed, they now perform in front of Australian indoor record crowds at the city's multi-million-dollar entertainment center. In 1984 the Foster's brewing company 
contributed $\$(A) 1,500$ to the Bullets and total sponsorship amounted to $\$(A) 7,500$. In 1988 the club received \$(A)1.1 million from Foster's, the largest single sponsorship deal in NBL history. In 1979, the NBL's first season, just under 200,000 Australians paid to watch basketball; in 1988 this figure exceeded 1 million. The NBL's income for 1990 was about \$(A) 15 million. In the 1970s, players were full-time workers and part-time athletes; many are now full-time athletes and some of the superstars earn well over $\$(A) 50,000$ per year. The league's most valuable player in 1990 was an American, who recently signed a 3 -year package that was rumored to be worth around $\$(A) 500,000$. These figures are modest in comparison to American professional sport, but significant in the context of Australian sport's amateur legacy and the economy of scale.

Some aspects of this commodification of sport are even more pronounced in Australia than in the USA. Many events and teams are named after owners and sponsors, and the players wear corporate logos on their uniforms. For instance, two of the teams in the NBL are called the Sydney NEC Kings and the Brisbane Foster's Bullets. The most popular horse and automobile races are called the Foster's Melbourne Cup and the Foster's Australian Grand Prix, respectively. We have yet to see the St. Louis Anheuser-Busch Cardinals in American baseball!

\section{All Stars and Stripes?}

In some ways then, it is evident that like the English case (cf. Maguire, 1990), sport in Australia has been Americanized. However, this term does not capture the complexity of the Australian scene. Australia has a polyethnic population and a mixed economy. This mix increasingly takes two commensurate forms. The first is a federal government policy of multiculturalism that evokes (and often funds) respect for lifestyle components of culture derived from places of origin, frequently including sport. So soccer is ethnically marked as Yugoslav, Greek, and Italian. The second is how the state tends to act as a broker between capital and community, encouraging or substituting "responsible" forms of sport sponsorship (for instance, "connecting" business and sport on the one hand; providing "healthy" funding to displace sponsorship offered by foreign multinational tobacco companies on the other).

Like Canada, Australia has a semiperipheral position in the capitalist world economy, so American economic and cultural influences are obvious. However, Australia's marginal status in the global market means that other countries also shape Australian popular culture. For instance, Australians can view British and European sports such as swimming, tennis, golf, soccer, rugby, boxing, skiing, snooker, skating, basketball, gymnastics, sailing, cricket, and track and field; telecasts of the World Cup, the summer and winter Olympics, and the Commonwealth Games always attract huge audiences. The publicly owned Australian Broadcasting Corporation (ABC) and Special Broadcasting Service (SBS) provide weekly coverage of games from English and European first division soccer leagues. In 1986 Australia's principal national daily newspaper, The Australian, sponsored the corporate team cup in the Sydney Wang Marathon and presented the award, for the second consecutive year, to the Esso squad.

The amateur Australian Basketball Federation is also dependent on this Japanese corporation for sustaining Australia's national team, the Wang 
Boomers. Australia's solo class sailing team is sponsored by Toyota. Australian tennis is partially supported by Britain's petrochemical company, BP, and the American fast-food chain, McDonald's. Until 1987 the NBL team in Canberra, the Cannons, was sponsored by Mazda. New Zealand Breweries has attempted to increase awareness of its premier beer, Steinlager, by sponsoring Rugby Union and yachting events. Dutch Shell was a major sponsor of the 1988 Bicentennial Women's Cricket World Cup; women's netball has been financed by Dunlop and Esso; Johnson \& Johnson, McDonald's, and BP have assisted junior girls' tennis (women's sports receive only a fraction of the total sponsorship money and media coverage).

The international, and in the corporate sense multinational, nature of Australian sport is illustrated by the recent acquisition of America's Cup hero Alan Bond's Australian breweries by New Zealand's Lion Nathan. When the takeover was announced, the Queensland minister for sport stated he would seek guarantees that the Lion Nathan brewery would continue the previous owner's tradition of sponsoring sport in his state. The minister stressed that he did not want Queenslanders subsidizing New Zealand's All Black Rugby Union team or its bid for the America's Cup. He insisted that "the money spent by Queensland beer drinkers should stay in our state to help our young sports stars."

Another example is the establishment of the National Baseball League in 1989. Each of the nine privately owned clubs has a working relationship with a major league team in the United States and carries a quota of four foreign nationals; one of the Sydney franchises is $90 \%$ American owned; in 1990 the league signed a million dollar sponsorship, development, and marketing deal with the American soft drink company Pepsi Cola. However, the Gold Coast entry is completely owned by the Japanese conglomerate Daikyo. The team comprises two Americans, one Taiwanese, and Australians. American and Japanese players and coaches conduct clinics in order to improve the level of Australian players. One can also see the emergence of an international division of labor in Australian sport. For top soccer players, the semiprofessional status of the local game is much less appealing than big money to be made in Europe. Australian universities are now introducing sporting scholarships, as many local athletes accept offers from American colleges.

Despite these pervasive overseas influences, domestic (male) sports have maintained or increased their share of television audiences. An annual best-ofthree series in Rugby League between Queensland and New South Wales usually tops the TV ratings poll in both states. Rugby League also commands a significant share of audiences on Friday nights and weekends in Queensland and New South Wales. On weekends, watching Australian Rules football predominates television viewing in Victoria, Tasmania, South Australia, and Western Australia. The NBL has also been highly successful in attracting viewers, with some games even being screened on Saturday evenings. In each case, administrators have sought to broaden the appeal of their sport by shifting the emphasis away from male spectators and toward the family viewer.

There has even been a limited amount of Australianization. Promoters have staged Australian Rules football contests in Canada, England, Japan, and the USA as well as Rugby League matches in Canada and the USA. Recently an Australian promoter arranged a series of exhibition cricket matches in New York. 
Australian companies, especially the Foster's and Fourex breweries, also sponsor American, Canadian, British, and New Zealand sports. ESPN recently dropped telecasts of Australian Rules football in the United States because of objections by Anheuser-Busch to the displays of the Foster's logo.

We do not believe that processes of professionalization and commodification are restricted to the culture of one nation. A concept such as Americanization (or "Japanization," which might be more appropriate given the current moral panic in Australia over Japanese property owners and developers) tends to flatten out, to homogenize, and to deny the rich heterogeneity and conflict both within and among the supposed donors and legatee. An alternative account of keynote changes in Australian sport might rather stress the growth of administrative management as an expression of modernity via the spread of formal rationality. From this point of view, the state is a critical player-cum-mediator in, for instance, governing populations via contradictory policies that articulate a professional, elite regimen of sport on one hand and a participatory model on the other.

Australian sport may have initially adopted American styles of producing and promoting sport, but its commodification cannot be typified as distinctly American. International image, sponsorship, and administration markets go far beyond the unidirectional logic of notions of straightforward cultural domination. We view the commodification processes described above as evidence of the integration of both amateur and professional sport into the media industries, advertising agencies, and multinational corporations of the capitalist world system. At a political level, Australia's adherence to the Gleneagles Agreement forbidding sporting ties with South Africa indicates the importance of the Commonwealth of Nations as a critical site of alternative allegiance/influence.

In trying to deal with the uptake of American sporting culture in Australia, particularly televised sporting culture, one is brought back again and again to a command metaphor of populist distillations of cultural imperialism. Such derivations can comprise quite contradictory components within the story world of a televisual text. Consider a controversy during the 1988 summer Olympics when the Australian anchor person said, "Those Americans, they're incredible aren't they?" with reference to an American commentator's alleged denigration of an Australian competitor. Yet the anchor was enunciating these words in a program very much formally based on the protocols of major American television sport production-play-by-play description, color commentators, deployment of technology, and editorial style. At a purely formal level this is mimicry; at the level of content it can be critique.

\section{Conclusion}

in advanced capitalism . . . the dominant culture reaches much further than ever in capitalist society into hitherto 'reserved' or 'resigned' areas of experience and practice and meaning. (Williams, 1978, pp. 125-126)

There is a rising awareness of the 'infiltration' of capital into areas of life which until now were sheltered from it by tradition and within which the values of capitalist society . . . were hitherto not dominant. (Habermas, 1979, p. 76) 
With regard to the relevance of Americanization to Australian sport, it should be evident that we find the concept to be of limited use. With regard to alternative perspectives, we will conclude by briefly indicating some approaches that we believe are pertinent for understanding the constitution of Australian sport. We have no one best way to recommend, since we concur with Johnson's (1987) view that the analysis of cultural processes is an interdisciplinary and antidisciplinary project.

Economically, we situate the recent transformation of Australian sport in the context of post-Fordism and the globalization of consumerism, all of which transcend the confines of the United States; culturally, we view the form and content of Australian sport as exemplifying the "cultural logic of late capitalism" (Jameson, 1984). Thus a critical perspective on mass communications is indispensable for understanding the political economy of Australian culture, as well as how the cultural and social technologies of the mass media legitimate, reify, and fragment everyday representations of social relations both in and through sport (Lawrence, 1986, 1990; Lawrence \& Rowe, 1986b; McKay \& Huber, 1988; in press; McKay \& Rowe, 1987; Miller, 1990; Rowe \& Lawrence, 1986; Williams, Lawrence, \& Rowe, 1986).

In reading Australian sport as a cultural text, it is important to understand its imbrication in a larger intertextual ensemble. Recently a variety of Australian and foreign companies have poured sponsorship money not just into sport but also into education, music, dance, cinema, art, and the nation's 1988 bicentennial celebrations, in order to demonstrate that they are good corporate citizens. In the discourse of the daily report from the stock exchange, the Americans are not the only players in the cultural game.

\section{References}

Adams, P. (1990, July 7-8). Southern cross: All stars and stripes. The Weekend Australian, p. 2.

Blainey, G. (1990, October 16). Victory for the American way. The Bulletin, pp. 32-33. Habermas, J. (1979). Conservatism and capitalist crisis. New Left Review, 115, 73-84.

James, P. (1986). The ideology of winning: Cultural politics and the America's Cup. In G. Lawrence \& D. Rowe (Eds.), Power play: Essays in the sociology of Australian sport (pp. 136-147). Sydney: Hale \& Iremonger.

Jameson, F. (1984). Postmodernism, or the cultural logic of late capitalism. New Left Review, 146, 53-92.

Johnson, R. (1987). What is cultural studies anyway? Social Text, 16, 38-80.

Lawrence, G. (1986). It's just not cricket. In G. Lawrence \& D. Rowe (Eds.), Power play: Essays in the sociology of Australian sport (pp. 151-165). Sydney: Hale \& Iremonger.

Lawrence, G. (1990). Football hooliganism: Australian media representations of the Heysel Stadium football riot. In D. Rowe \& G. Lawrence (Eds.), Sport and leisure: Trends in Australian popular culture (pp. 40-58). Sydney: Harcourt Brace Jovanovich.

Lawrence, G., \& Rowe, D. (Eds.) (1986a). Power play: Essays in the sociology of Australian sport. Sydney: Hale \& Iremonger. 
Lawrence, G. , \& Rowe, D. (1986b). Cricket: The corporate pitch. In G. Lawrence \& D. Rowe (Eds.), Power play: Essays in the sociology of Australian sport (pp. 166178). Sydney: Hale \& Iremonger.

Macintosh, D., \& Whitson, D. (1990). The game planners. Montreal \& Kingston: McGill-Queens University Press.

Maguire, J. (1990). More than a sporting touchdown: The making of American football in England 1982-1990. Sociology of Sport Journal, 7, 213-237.

Mandle, W. (1978). Pommy bastards and damn Yankees: Sport and Australian nationalism. In W. Mandle, Going it alone: Australia's national identity in the twentieth century (pp. 24-46). Ringwood: Penguin.

McKay, J. (1986). Hegemony, the state and Australian sport. In G. Lawrence \& D. Rowe (Eds.), Power play: Essays in the sociology of Australian sport (pp. 115-135). Sydney: Hale \& Iremonger.

McKay, J. (1990). Sport, leisure and social inequality in Australia. In D. Rowe \& G. Lawrence (Eds.), Sport and leisure: Trends in Australian popular culture (pp. 125-160). Sydney: Harcourt Brace Jovanovich.

McKay, J. (in press). No pain, no gain: Sport and contemporary culture. Sydney: Prentice Hall Australia.

McKay, J., \& Huber, D. (1988). Swan sport and ideology. Arena, 83, 117-134.

McKay, J., \& Huber, D. (in press). Anchoring media images of technology and sport. Women's Studies International Forum.

McKay, J., \& Rowe, D. (1987). Ideology, the media and Australian sport. Sociology of Sport Journal, 4, 258-273.

Miller, T. (1989). World series sound and vision. Meanjin, 48, 591-596.

Miller, T. (1990). Sport, media and masculinity. In D. Rowe \& G. Lawrence (Eds.), Sport and leisure: Trends in Australian popular culture (pp. 74-95). Sydney: Harcourt Brace Jovanovich.

Poynton, B., \& Hartley, J. (1990). Male gazing: Australian rules football, gender and television. In M. Brown (Ed.), Television and women's culture (pp. 144-157). London: Sage.

Rowe, D., \& Lawrence, G. (1986). Saluting the state: Nationalism and the Olympics. In G. Lawrence \& D. Rowe (Eds.), Power play: Essays in the sociology of Australian sport (pp. 196-203). Sydney: Hale \& Iremonger.

Rowe, D., \& Lawrence, G. (Eds.) (1990). Sport and leisure: Trends in Australian popular culture. Sydney: Harcourt Brace Jovanovich.

Stratton, J. (1986). Australia-This sporting life. In G. Lawrence \& D. Rowe (Eds.), Power play: Essays in the sociology of Australian sport (pp. 85-114). Sydney: Hale \& Iremonger.

Williams, C., Lawrence, G., \& Rowe, D. (1986). Patriarchy, media and sport. In G. Lawrence \& D. Rowe (Eds.), Power play: Essays in the sociology of Australian sport (pp. 215-229). Sydney: Hale \& Iremonger.

Williams, R. (1978). Marxism and literature. Oxford: Oxford University Press. 